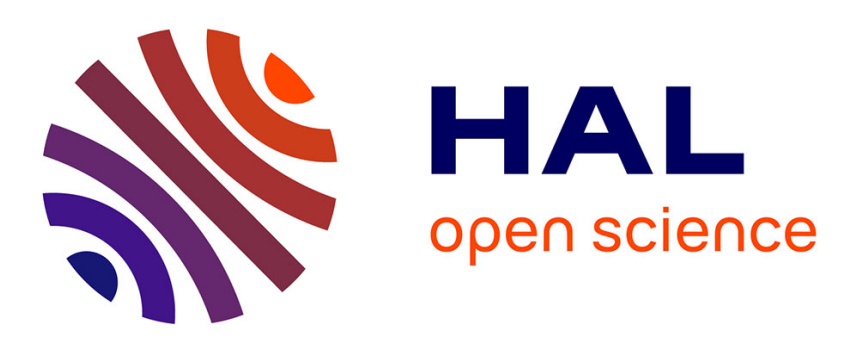

\title{
Nanosized silver-anionic clay matrix as nanostructured ensembles with antimicrobial activity
}

\author{
Gabriela Carja, Yoshikazu Kameshima, Akira Nakajima, Cristian Dranca,
} Kiyoshi Okada

\section{- To cite this version:}

Gabriela Carja, Yoshikazu Kameshima, Akira Nakajima, Cristian Dranca, Kiyoshi Okada. Nanosized silver-anionic clay matrix as nanostructured ensembles with antimicrobial activity. International Journal of Antimicrobial Agents, 2009, 34 (6), pp.534. 10.1016/j.ijantimicag.2009.08.008 . hal00556361

\section{HAL Id: hal-00556361 https://hal.science/hal-00556361}

Submitted on 16 Jan 2011

HAL is a multi-disciplinary open access archive for the deposit and dissemination of scientific research documents, whether they are published or not. The documents may come from teaching and research institutions in France or abroad, or from public or private research centers.
L'archive ouverte pluridisciplinaire HAL, est destinée au dépôt et à la diffusion de documents scientifiques de niveau recherche, publiés ou non, émanant des établissements d'enseignement et de recherche français ou étrangers, des laboratoires publics ou privés. 


\section{Accepted Manuscript}

Title: Nanosized silver-anionic clay matrix as nanostructured ensembles with antimicrobial activity

Authors: Gabriela Carja, Yoshikazu Kameshima, Akira

Nakajima, Cristian Dranca, Kiyoshi Okada

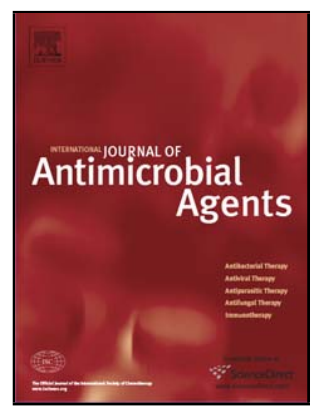

PII:

S0924-8579(09)00400-2

DOI: doi:10.1016/j.ijantimicag.2009.08.008

Reference: ANTAGE 3113

To appear in:

International Journal of

Antimicrobial

Agents

Received date:

2-6-2009

Revised date:

$12-8-2009$

Accepted date:

13-8-2009

Please cite this article as: Carja G, Kameshima Y, Nakajima A, Dranca C, Okada K, Nanosized silver-anionic clay matrix as nanostructured ensembles with antimicrobial activity, International Journal of Antimicrobial Agents (2008), doi:10.1016/j.ijantimicag.2009.08.008

This is a PDF file of an unedited manuscript that has been accepted for publication. As a service to our customers we are providing this early version of the manuscript. The manuscript will undergo copyediting, typesetting, and review of the resulting proof before it is published in its final form. Please note that during the production process errors may be discovered which could affect the content, and all legal disclaimers that apply to the journal pertain. 


\section{Nanosized silver-anionic clay matrix as nanostructured ensembles with antimicrobial activity}

Gabriela Carja $^{\mathrm{a}, \star}$, Yoshikazu Kameshima ${ }^{\mathrm{b}}$, Akira Nakajima ${ }^{\mathrm{b}}$, Cristian Dranca ${ }^{\mathrm{a}}$, Kiyoshi Okada $^{\mathrm{c}}$

${ }^{a}$ Department of Chemical Engineering, Faculty of Chemical Engineering and Environment Protection, Technical University 'Gh. Asachi' of Iasi, Bd. D. Mangeron, Iasi 700554, Romania

${ }^{\mathrm{b}}$ Department of Metallurgy and Ceramics Science, Tokyo Institute of Technology 2-12-

1, O-okayama, Meguro-ku, Tokyo 152-8550, Japan

${ }^{c}$ Materials and Structures Laboratory, Tokyo Institute of Technology, 4259 Nagatsuta, Midori, Yokohama 226-8503, Japan

ARTICLE INFO

Article history:

Received 2 June 2009

Accepted 13 August 2009

Keywords:

Silver nanoparticles

LDH anionic clay

Antimicrobial properties 
Nanostructured ensembles

* Corresponding author. Tel.: +40 232201 231; fax: +40 232201231.

E-mail address: carja@uaic.ro (G. Carja). 


\section{ABSTRACT}

Nanostructured ensembles of silver nanoparticles/zinc-substituted anionic clay matrix $(\mathrm{Ag} / \mathrm{ZnLDH})$ were obtained by a simple synthetic route in which reconstruction of the layered clay, synthesis of the silver nanoparticles and their organisation on the clay surface took place in a single step at room temperature. The morphology, composition and phase structure of the prepared powders were characterised by X-ray diffraction, infrared spectroscopy, transmission electron microscopy, X-ray photoelectron spectroscopy and $\mathrm{N}_{2}$ adsorption. Results showed that the silver-anionic clay nanoarchitecture consists of nanoparticles of silver (average size $7 \mathrm{~nm}$ ) deposited on the larger nanoparticles of clay (average size $85 \mathrm{~nm}$ ). The antimicrobial activity was examined by disk diffusion assay and minimal inhibitory concentration determination as a function of $x$, where $x$ is a controlled variable parameter that represents the length of time since the sample was synthesised. Ag/ZnLDH showed more stable antimicrobial properties than the unsupported nanosized silver. 


\section{Introduction}

Ensembles of different nanostructures that are able to combine their characteristics and to organise themselves to create materials with complex properties have great potential in biomedical applications owing to the particular interactions that can be established between nanoscale architectures and biological interfaces [1]. Recently, silver nanoparticles have attracted a great deal of attention in biomedical applications owing to their surface plasmon resonance effect and antibacterial activity $[2,3]$. Synthesis of silver nanoparticles has been achieved by various routes consisting of complex synthesis/reduction procedures such as co-precipitation, microemulsion, sonochemical and photochemical techniques [4]. Nanoparticles of silver, as for all other nanosized metals, are easily aggregated and this aggregation behaviour is the cause of the in vitro and/or in vivo toxicity of metal nanoparticles $[5,6]$. A variety of organic solvents, stabilisers or coating agents (such as polymers, ligands or surfactants) have been used to reduce aggregation and stabilise the nanoparticles. These large organic compounds not only increase the cost of the obtained material but also strongly decrease the purity and accessibility of the active nanosites [7]. Moreover, organic additives are able to alter the interactions of the active nanosite with biological interfaces. An ensemble of metal nanoparticles/biocompatible inorganic matrix can improve these problems [8]. The inorganic matrix is also able to bring into the cumulative structure its own characteristics and thus a controlled textural organisation within nano range can be tailored, considering that textural features are very important for tuning the characteristics of the physicochemical processes occurring at biologically active interfaces [9]. Hydrotalcite, like anionic clays or more generally speaking layered double hydroxides (LDHs), 
represented by the empirical formula $\left[\mathrm{M}(\mathrm{II})_{1-\mathrm{x}} \mathrm{M}(\mathrm{III})_{\times}(\mathrm{OH})_{2}\right]^{\mathrm{x}^{+}}\left(\mathrm{A}^{\mathrm{n}-}\right) \cdot \mathrm{mH}_{2} \mathrm{O}$, are synthetic anionic clays with brucite $\left[\mathrm{Mg}(\mathrm{OH})_{2}\right]$-like layers in which some of the divalent cations have been replaced by trivalent ions. The cationic layers are bound together by the interlayer counter anions as well as by water molecules [10]. Intense research has recently been carried on LDH-like materials, mainly due to the ability of the porous clay matrix to incorporate and to transport various bio and organic molecules. The results show the ability of LDHs to allow cells to grow well and to function properly or even to force living cells to make changes according to the nature of the particular biomolecules $[11,12]$. The LDH clay matrix is also able to bring into a cumulative structure not only the advantage of good biocompatibility and controlled textural features $[13,14]$ but also high adsorption and ion exchange capacities [15]. It was also reported that the particular texture of the LDH allows bacteria and viruses to adsorb on the clay matrix [12] and thus to interact closely with the supported nanoparticles. A special characteristic of the anionic clay matrix is the so-called structural 'memory effect'. This means that the layered clay structure can be destroyed by calcination at moderate temperatures (ca. $550^{\circ} \mathrm{C}$ ) to yield low crystalline mixed oxides and then reconstructed by treatment with aqueous solutions containing anionic species $[16,17]$. In view of all this information, our work has focused on obtaining nanostructured ensembles able to combine the properties of the biocompatible matrix of the anionic clay and the specific induced characteristics of the nanosized metals into one single material. To our knowledge, we report here for the first time a nanosized silver $(\mathrm{Ag}) /$ zinc-substituted anionic clay matrix $(\mathrm{ZnLDH})$ as a new nanostructured formulation with antibacterial properties. We present a simple and straightforward synthesis route in which the reconstruction process of the 
clay (based on its structural memory), the formation of silver nanoparticles and their self-organisation on the surface of the larger nanoparticles of the $\mathrm{Zn}$-substituted hydrotalcite-like clay are performed in a single step at room temperature. No organic additives were used during the synthesis process of the clay-silver nanostructured ensemble.

\section{Materials and methods}

\subsection{Sample preparation}

The zinc-substituted hydrotalcite-like clay (denoted as $\mathrm{ZnLDH}$ ) was obtained by the coprecipitation method following the procedure of Reichle et al. [18]. Briefly, $500 \mathrm{~mL}$ of the aqueous solution of the metal salts used as precursors $\left[\mathrm{Zn}(\mathrm{NO})_{3} \cdot 6 \mathrm{H}_{2} \mathrm{O} / \mathrm{Al}\left(\mathrm{NO}_{3}\right)_{3} \cdot 9 \mathrm{H}_{2} \mathrm{O}\right.$ molar ratio 2/1] and the aqueous solution (1 M) of the precipitants $\mathrm{NaOH} / \mathrm{Na}_{2} \mathrm{CO}_{3}$ were added drop-wise together at $65^{\circ} \mathrm{C}$ at a constant $\mathrm{pH}$ 9. The white precipitate was aged at $45^{\circ} \mathrm{C}$ for $12 \mathrm{~h}$, separated by centrifugation, washed extensively with warm doubledeionised water until sodium free and dried in an oven at $85^{\circ} \mathrm{C}$. For the calcined clay (denoted as $\mathrm{ZnLDH550)}$, the parent clay $(\mathrm{ZnLDH})$ was calcined at $550{ }^{\circ} \mathrm{C}$ for $20 \mathrm{~h}$. For the silver-clay ensemble, denoted as Ag/ZnLDH, the 'freshly' calcined clay was added to $200 \mathrm{~mL}$ of aqueous solution $\left(1 \mathrm{~N}\right.$ ) of $\mathrm{Ag}_{2} \mathrm{SO}_{4}$ (containing $\mathrm{SO}_{4}{ }^{2-}$ and $\mathrm{Ag}^{+}$) at a constant $\mathrm{pH}$ value, with stirring, under a nitrogen atmosphere. The $\mathrm{SO}_{4}{ }^{2-}$ anions from the aqueous medium were used as an anion source during the clay reconstruction. The obtained sample was aged at ambient temperature, washed, centrifuged and dried 
under vacuum. The reconstruction process of the clay was carried out under natural sunlight (when the reduction of silver is described as $\mathrm{Ag}_{2} \mathrm{O} \stackrel{h v}{\longrightarrow} \mathrm{Ag}$ [19]).

\subsection{Instruments and techniques}

Elemental analyses were performed by inductively coupled plasma (ICP) spectroscopy using solutions prepared by dissolving the samples in dilute $\mathrm{H}_{2} \mathrm{SO}_{4}$. X-ray powder diffraction patterns were recorded on a Shimadzu XRD-6100 diffractometer (Shimadzu Corp., Tokyo, Japan) using monochromatic Cu K $\alpha$ radiation $(\lambda=0.154 \mathrm{~nm})$, operating at $40 \mathrm{kV}$ and $30 \mathrm{~mA}$ over a $2 \theta$ range from $4^{\circ}$ to $70^{\circ}$. A Quantachrome automated gas adsorption system (AUTOSORB-1; Quantachrome Instruments, Boynton Beach, FL) was used to obtain $\mathrm{N}_{2}$ adsorption isotherms at $77 \mathrm{~K}$; the BET specific surface area $\left(\mathrm{S}_{\mathrm{BET}}\right)$ was calculated using the standard Brunauer, Emmett and Teller method on the basis of the adsorption data. X-ray photoelectron spectroscopy (XPS) spectra were recorded using a Perkin-Elmer spectrometer (Model 5500-MT; Perkin-Elmer Inc., Norwalk, CT) equipped with $\mathrm{Mg} \mathrm{K \alpha}$ radiation (1253.6 eV) operating at $15 \mathrm{kV}$ and $20 \mathrm{~mA}$; the binding energies $(\mathrm{BE})$ were corrected by referencing the $\mathrm{C} 1 \mathrm{~s}$ peak to $284.8 \mathrm{eV}$. Transmission electron microscopy (TEM) analysis was performed on a Hitachi $\mathrm{H}-900$ instrument (Hitachi Ltd., Tokyo, Japan) operating at 200 kV. The Fourier transform infrared (FTIR) spectra were collected on a Perkin-Elmer spectrophotometer (Spectrum 100; Perkin-Elmer Inc., Shelton, CT) in the wave number range $450-4000 \mathrm{~cm}^{-1}$ at a resolution of $4 \mathrm{~cm}^{-1}$ using $\mathrm{KBr}$ pellets. 


\subsection{Antimicrobial activity tests}

ZnLDH, ZnLDH550 and Ag/ZnLDH were screened for their antibacterial activity against the Gram-positive bacterium Staphylococcus aureus (ATCC 25923) and the Gramnegative bacterium Escherichia coli (ATCC 35218). Unsupported silver nanoparticles (average size $7 \mathrm{~nm}$ ), obtained according to the procedure described by Chen et al. [14], were denoted as $\mathrm{Ag}_{\mathrm{N}}$ and were used as a reference sample of the antibacterial activity. All materials were sterilised in an autoclave before experiments. The antibacterial activities of the tested materials were qualitatively and quantitatively assessed by agar diffusion tests and minimal inhibitory concentration (MIC) values, respectively [20]. Tubes containing $10 \mathrm{~mL}$ of solution of the tested sample (the mass of the sample from the tube was calculated in such a way as to achieve a concentration of silver ranging from $2.5 \mu \mathrm{g} / \mathrm{mL}$ to $25 \mathrm{mg} / \mathrm{L}$ ) were placed onto an agar plate seeded with $10^{7}$ colonyforming units $(\mathrm{CFU}) / \mathrm{mL}$ of microorganisms. After $24 \mathrm{~h}$ of incubation at $37^{\circ} \mathrm{C}$, the diameters of the inhibition zones were measured. MIC values were determined as the lowest concentration of the tested sample where the absence of growth was recorded [20]. Three replicate experiments were performed.

\section{Results and discussion}

\subsection{Structural and surface characteristics of Ag/ZnLDH described by X-ray diffraction} $(X R D)$ and $X$-ray photoelectron spectroscopy (XPS) results

The XRD patterns of the samples are shown in Fig. 1. ZnLDH crystallised in the hydrotalcite-like phase, without any crystalline impurity, with a series of sharp and 
symmetric basal reflections $(00 \ell, \ell=3,6)$ and broad, less intense, non-basal reflections $(01 \ell, \ell=2,5,8)$. The other reflections of (110) and (113) can be clearly distinguished around $2 \theta=60^{\circ}$, thus pointing out a decreased intralayer disorder of the $\mathrm{Zn}$-containing clay network [10]. Calcination at $550^{\circ} \mathrm{C}$ for $20 \mathrm{~h}$ destroys the LDH layered network. The characteristic sharp, well shaped reflections in the sample can be ascribed to crystalline $\mathrm{ZnO}$ (wurtzite JCPDS file no. 36-1451), as indicated by the presence of peaks of $2 \theta=$ $31.9,34.5,36.3,47.6,56.8,62.9$ and $68.2^{\circ}$, corresponding to the reflections of (100), (002), (101), (102), (110), (103) and (112), respectively. ZnAl mixed oxides or spineltype phases are not observed after calcination of the $\mathrm{ZnLDH}$ clay at $550^{\circ} \mathrm{C}$. Ag/ZnLDH displays some sets of reflections, thus indicating complex structural characteristics of the sample. The reflections marked with ' $\mathrm{\prime}$ ' can be indexed to the regained LDH structure when the calcined clay was introduced in the aqueous medium of $\mathrm{Ag}_{2} \mathrm{SO}_{4}$, containing $\mathrm{Ag}^{+}$and $\mathrm{SO}_{4}{ }^{2-}$ ions, whilst the reflections marked with '*' can be assigned to metallic Ag (JCPDS file no. 04-0783). The characteristic reflections of $\mathrm{ZnO}$ can still be observed, thus revealing that the reconstruction process of the clay was not complete. The evolution of $\mathrm{Ag} / \mathrm{ZnLDH}$ is followed after its calcination at $550^{\circ} \mathrm{C}$ for $20 \mathrm{~h}$ (in Fig. 1 this sample is denoted by $\mathrm{Ag} / \mathrm{ZnLDH550)}$. The characteristics of the thermally treated silver-clay ensemble indicate that the intensity and sharpness of the reflections situated at $2 \theta$ angles $=37.9,44.0$ and $63.9^{\circ}$ (corresponding to the main reflections of metallic silver) accentuated; this can be a consequence of the aggregation process of the silver nanoparticles after thermal treatment at $550^{\circ} \mathrm{C}$ [5]. Information about the chemical composition of the samples is presented in Table 1. The $\mathrm{Zn} / \mathrm{Al}$ atomic ratio, as determined by ICP spectroscopy, coincides within experimental errors with those of the 
starting aqueous salts solutions. The surface chemical states of the elements of the samples were investigated by XPS. Figure 2 illustrates the overall survey and Ag3d XPS spectra for the Ag/ZnLDH ensemble. The survey spectrum includes the characteristic peaks of $\mathrm{Zn} 2 \mathrm{p}_{3 / 2}(1022.7 \mathrm{eV}), \mathrm{Al} 2 \mathrm{p}(73.87 \mathrm{eV}), \mathrm{Ag} 3 \mathrm{~d}$ and O1s with all the binding energies referenced to $\mathrm{C} 1 \mathrm{~s}(284.8 \mathrm{eV})$. For the $\mathrm{Ag} 3 \mathrm{~d}$ region, the $\mathrm{Ag} 3 \mathrm{~d}_{3 / 2}$ and Ag3d $d_{5 / 2}$ peaks appear at binding energies of $373.12 \mathrm{eV}$ and $367.17 \mathrm{eV}$, respectively. These binding energy values are very similar to those reported for silver in the $\mathrm{Ag} / \mathrm{ZnO}$ formulation [19,21]; the complex electronic environment on the surface of the $\mathrm{Ag}-\mathrm{Zn}$ heterostructure reveals strong electronic interactions between silver and zinc [22]. The O1s peak (Fig. 3) can be deconvoluted in two peaks. The first one $\left(\mathrm{O}_{1}\right)$, with the lower binding energy (equal to $529.4 \mathrm{eV}, 529.7 \mathrm{eV}$ and $530.1 \mathrm{eV}$ for Ag/ZnLDH, ZnLDH and ZnLDH550, respectively), is associated with the lattice oxygen bound to metal cations, whilst the second one $\left(\mathrm{O}_{\|}\right)$, with the higher binding energy at ca. $531.4 \mathrm{eV}$, most likely belongs to the surface oxygen, consisting mainly of oxygen species of hydroxyl groups [23]. The relative abundance of these two oxygen species (calculated as $\%$ peak area of $\mathrm{O}_{\text {I }}$ and $\mathrm{O}_{\|}$peaks in the total area of $\mathrm{O} 1 \mathrm{~s}$ peak) is listed in Table 1. It is revealed that the contribution of the oxygen bound to the metal cations increases in comparison with that of the oxygen belonging to the surface hydroxyl groups in the order: $\mathrm{ZnLDH}<$ ZnLDH550 < Ag/ZnLDH. Pawlak et al. [24] reported very useful information about the specific particularities of XPS data. According to their results, the more ionic character the countercation has, the lower the binding energies of the framework elements. In the case of the Ag-LDH material, the valence electron of $\mathrm{O}$ will be shifted less toward the $\mathrm{Ag}$ in the $\mathrm{Zn}-\mathrm{O}-\mathrm{Ag}$ formulation than toward the $\mathrm{Zn}$ in the $\mathrm{Zn}-\mathrm{O}-\mathrm{Zn}$, and the electron 
density is greater near the $\mathrm{O}$ in the $\mathrm{Ag} / \mathrm{ZnLDH}$ than near the $\mathrm{O}$ in the $\mathrm{ZnLDH}$; as a consequence, the binding energy of oxygen in $\mathrm{Ag} / \mathrm{ZnLDH}$ is observed at a lower value than $\mathrm{ZnLDH}$, thus indicating that specific interactions are established in the silver-clay nanostructured ensemble.

3.2. Micromorphology and textural characteristics of $A g / Z n L D H$ described by the results of transmission electron microscopy and $\mathrm{N}_{2}$ adsorption

TEM analysis offers a closer look at the morphological features of the new material. The TEM image of ZnLDH550 (Fig. 4) indicates a rough and clean surface to the clay particles. The average particle size of the LDH, obtained from scanning electron microscopy (image not shown), is $85 \mathrm{~nm}$. For the silver-clay structure, the TEM picture (Fig. 5) reveals that silver nanoparticles (average diameter $7 \mathrm{~nm}$ ) exist on the larger nanoparticles of zinc-substituted clay. The selected area electron diffraction (SAED) pattern of $\mathrm{Ag} / \mathrm{ZnLDH}$ (Fig. 5) displays a complex diffraction ring pattern in which the (111), (200), (220) and (311) planes of metallic silver can be identified $[25,26]$. Together the TEM and XRD results point out that, when the memory effect of the clay has manifested in the $\mathrm{Ag}_{2} \mathrm{SO}_{4}$ solution, a $\mathrm{LDH}$-layered structure supported with silver nanoparticles evolved. Other textural characteristics of the samples are listed in Table 1. The $B E T$ surface area value $\left(S_{B E T}\right)$ is $79 \mathrm{~m}^{2} / g$ for $Z n L D H$ and reaches a maximum value after the calcination process $\left(134 \mathrm{~m}^{2} / \mathrm{g}\right)$, although it decreases to $55 \mathrm{~m}^{2} / \mathrm{g}$ for Ag/ZnLDH. The average pore diameter $d_{p}$, calculated from the classical Gurvitsch rule [27], decreases from $38 \mathrm{~nm}$ for $\mathrm{ZnLDH}$ to $19 \mathrm{~nm}$ for $\mathrm{Ag} / \mathrm{ZnLDH}$, revealing that the mesoporous characteristics are retained in the silver-clay ensemble. 


\subsection{Nature of the clay interlayer anions studied by Fourier transform infrared spectroscopy}

FTIR spectroscopy analysis is able to give information about the nature of the anions in the clay interlayers. The FTIR patterns reveal some similarity for the ZnLDH and the Ag/ZnLDH layered structures (Fig. 6). The broad absorption peaks in the region 2800 $3600 \mathrm{~cm}^{-1}$ and $1560 \mathrm{~cm}^{-1}$ are attributed to the $\mathrm{O}-\mathrm{H}$ symmetric stretching mode and bending modes in the metal hydroxide layers or interlayer water molecules. The band corresponding to the bending mode $\delta_{\mathrm{OH}}$ appears between $1644-648 \mathrm{~cm}^{-1}$ and may be assigned to the adsorbed interlayer water [22]. An intense absorption band between $1370-1383 \mathrm{~cm}^{-1}$ is attributed to the $v_{3}$ vibration mode of $\mathrm{CO}_{3}{ }^{2-}$ [23]. In the same range, the $v_{3}$ vibration mode of the nitrate could appear if this still exists in the interlayer. For $\mathrm{Ag} / \mathrm{ZnLDH}$, a new band was observed at $1122 \mathrm{~cm}^{-1}$ assigned as the $v_{3}$ vibration mode of $\mathrm{SO}_{4}{ }^{2-}$, and as a consequence the presence of $\mathrm{SO}_{4}$ can be recognised in the clay interlayer. In the low wave number region $\left(<1000 \mathrm{~cm}^{-1}\right)$, the lattice vibration modes of the LDH sheets such as M-O $\left(550,590\right.$ and $\left.840 \mathrm{~cm}^{-1}\right)$ and O-M-O $\left(430 \mathrm{~cm}^{-1}\right)$ vibrations are observed [28]. For the freshly calcined clay (ZnLDH550), the characteristic vibrations in the range $1370-1560 \mathrm{~cm}^{-1}$ almost disappear, revealing that the interlayer anions were removed following calcination. 


\subsection{Antimicrobial activity}

Antibacterial effects in the form of inhibition zones of the tested samples are summarised in Table 2. The antibacterial effects of the $\mathrm{Ag} / \mathrm{ZnLDH}$ and $A g_{N}$ are compared as a function of $x$ as a controlled variable parameter, where $x$ describes the age of the sample. More precisely, $x$ represents the number of weeks or months since the sample was synthesised. During this time, all the tested samples were carefully stored under similar conditions, in a dessicator, at $22^{\circ} \mathrm{C}$. After $24 \mathrm{~h}$ of incubation, the zone of inhibition of Ag/ZnLDH against $E$. coli and S. aureus decreased slightly from $14.7 \mathrm{~mm}(x=1$ day $)$ to $12.4 \mathrm{~mm}(x=3$ months $)$ and from $11.9 \mathrm{~mm}(x=1$ day $)$ to 7.0 $\mathrm{mm}\left(x=3\right.$ months), respectively. When $\mathrm{Ag}_{\mathrm{N}}$ was tested, the inhibition zone values decreased greatly from $12.4 \mathrm{~mm}$ for $x=1$ day to $3.0 \mathrm{~mm}$ for $x=3$ months against $E$. coli. The zone of inhibition was equal to $11 \mathrm{~mm}(x=1$ day $)$ and reached $0 \mathrm{~mm}(x=1.5$ months) against $S$. aureus. The parent $Z n L D H$ clay, in the as synthesised and the calcined form, does not show any bacterial activity. These results reveal the increased stability of the silver-clay formulation in comparison with that of $\mathrm{Ag}_{\mathrm{N}}$ (Table 2). For $\mathrm{Ag} / \mathrm{ZnLDH}$, the MIC values against $E$. coli was $0.3 \mu \mathrm{g} / \mathrm{mL}$ for $x$ in the range 1 day to 1 month and increased to $0.5 \mu \mathrm{g} / \mathrm{mL}$ when $x=2$ months (Table 3 ). The better stability and efficacy of the antibacterial activity of $A g / Z n L D H$ is possibly due to the ability of the LDH matrix to adsorb microorganisms, thus facilitating better interactions with the silver nanoparticles from the surface. 


\section{Concluding remarks}

A nanosized silver-anionic clay formulation was tested as a new antimicrobial agent. The antibacterial activity of the silver-clay nanoarchitecture was compared with that of the unsupported silver nanoparticles. A simple synthesis route was developed in which the reconstruction process of the anionic clay, the synthesis of the silver nanoparticles and their deposition on the clay matrix were done in a single step at room temperature.

\section{Funding}

The support of contract PNCDI II NATOEPA 71-020/2007 and CNCSIS IDEI 323/2009 is gratefully acknowledged.

\section{Competing interests}

None declared.

\section{Ethical approval}

Not required. 


\section{References}

[1] Hornebecq V, Antonietti M, Cardinal T, Treguer-Delapierre M. Stable silver nanoparticles immobilized in mesoporous silica. Chem Mater 2003;15:1993-9.

[2] Huang S, Yang P, Cheng Z, Li C, Fan Y, Kong D, et al. Synthesis and characterization of magnetic $\mathrm{Fe}_{x} \mathrm{O}_{y}-\mathrm{SBA}-15$ composites with different morphologies for controlled drug release and targeting. J Phys Chem C Nanomater Interfaces 2008;112:7130-7.

[3] Merga G, Wilson R, Lynn G, Milosavljevic BH, Meisel D. Redox catalysis on 'naked' silver nanoparticles. J Phys Chem C Nanomater Interfaces 2007;111:12220-6.

[4] Rai M, Yadav A, Gade A. Silver nanoparticles as a new generation of antimicrobials. Biotechnol Adv 2009;27:76-83.

[5] Dawn A, Mukherjee P, Nandi AK. Preparation of size-controlled, highly populated, stable, and nearly monodispersed Ag nanoparticles in an organic medium from a simple interfacial redox process using a conducting polymer. Langmuir 2007;23:5231-7.

[6] Lengke MF, Fleet ME, Southam G. Biosynthesis of silver nanoparticles by filamentous cyanobacteria from a silver(I) nitrate complex. Langmuir 2007;23:26949.

[7] Zhang H, Fu Q, Yao Y, Zhang Z, Ma T, Tan D, et al. Size-dependent surface reactions of Ag nanoparticles supported on highly oriented pyrolytic graphite. Langmuir 2008;24:10874-8. 
[8] Kim YH, Lee DK, Cha HG, Kim CW, Kang YS. Synthesis and characterization of antibacterial $\mathrm{Ag}-\mathrm{SiO}_{2}$ nanocomposite. J Phys Chem C Nanomater Interfaces 2007;111:3629-35.

[9] Berry CC. Possible exploitation of magnetic nanoparticle-cell interaction for biomedical applications. J Mater Chem 2005;15:543-7.

[10] Perez Ramirez J, Guido M, Kaptejin F, Moulijn J. In situ investigation of the thermal decomposition of Co-Al hydrotalcite in different atmospheres. J Mater Chem $2001 ; 11: 821-30$.

[11] Kwak SY, Kriven WM, Wallig MA, Choy JH. Inorganic delivery vector for intravenous injection. Biomaterials 2004;25:5995-6001.

[12] Nakayama H, Wada N, Tsuhako M. Intercalation of amino acids and peptides into Mg-Al layered double hydroxide by reconstruction method. Int J Pharm 2004;269:469-78.

[13] Rajamathi JT, Arulraj A, Ravishankar N, Arulraj J, Rajamathi M. Delamination of surfactant-intercalated brucite-like hydroxy salts of cobalt and copper and solvothermal decomposition of the resultant colloidal dispersions. Langmuir 2008;24:11164-7.

[14] Chen M, Wang LY, Han JT, Zhang JY, Li ZY, Qian DJ. Preparation and study of polyacryamide-stabilized silver nanoparticles through a one-pot process. J Phys Chem B 2006;110:11224-31.

[15] Intissar M, Malherbe F, Prevot $\mathrm{V}$, Leroux $\mathrm{F}$. Evidences of segregated $\mathrm{SnO}_{2}$ type nanoparticles coating layered double hydroxide at moderate temperature. J Colloid Interface Sci 2006;299:747-53. 
[16] Jin S, Fallgren PH, Morris JM, Chen Q. Removal of bacteria and viruses from waters using layered double hydroxide nanocomposites. Sci Technol Adv Mater 2007;8:67-70.

[17] Carja G, Nakamura R, Niiyama H. Tailoring the porous properties of iron containing mixed oxides. Microporous Mesoporous Mater 2005;94:83-7.

[18] Reichle WT, Yang SY, Everhardt SD. The nature of the thermal decomposition of a catalytically active anionic clay mineral. J Catal 1986;10:352-7.

[19] Zheng Y, Chen C, Zhan Y, et al. Photocatalytic activity of Ag/ZnO heterostructure nanocatalyst: correlation between structure and property. J Phys Chem C Nanomater Interfaces 2008;112:10773-7.

[20] Li Y, Leung P, Yao L, Song QW, Newton E. Antimicrobial effect of surgical masks coated with nanoparticles. J Hosp Infect 2006;62:58-64.

[21] Evanoff DD, Chumanov G. Measuring the distance dependence of the local electromagnetic field from silver nanoparticles. J Phys Chem B 2004;108:13948-56.

[22] Moulder JF, Stickle WF, Sobol PE, Bomben KD, editors. Handbook of X-ray photoelectron spectroscopy. 2nd ed. Eden Prairie, MN: Perkin-Elmer Corp. (Physical Electronics); 1992.

[23] Elechiguerra JL, Larios-Lopez L, Liu C, Garcia-Gutierrez D, Camacho-Bragado A, Yacaman MJ. Corrosion at the nanoscale: the case of silver nanowires and nanoparticles. Chem Mater 2005;17:6042-52.

[24] Pawlak DA, Ito M, Oku M, Shimamura K, Fukuda T. Interpretation of XPS O (1s) in mixed oxides proved on mixed perovskite crystals. J Phys Chem B 2002;106:5047. 
[25] Chen $\mathrm{DH}$, Chen CJ. Formation and characterization of Au/Ag bimetallic nanoparticles in water-in-oil microemulsions. J Mater Chem 2002;12:1557-62.

[26] Roy B, Chakravorty D. Electrical conductance of silver nanoparticles grown in glass-ceramic. J Phys Condens Matter 1990;2:9323-34.

[27] Jaroniec M, Kruk M, Sayari A. Adsorption methods for characterization of surface and structural properties of mesoporous molecular sieves. In: Bonneviot L, Beland F, Danumah C, Giasson S, Kaliaguine S, editors. Mesoporous molecular sieves 1998. Amsterdam, The Netherlands: Elsevier; 1998. p. 325-32.

[28] Del Arco M, Rives V, Trujillano R, Mallet P. The layered double hydroxide (LDH) of $\mathrm{Zn}$ with Ga: synthesis and reversible thermal behaviour. J Mater Chem 1996;6:1419-28. 
Fig. 1. X-ray diffraction (XRD) patterns of the studied samples. ZnLDH, zinc-substituted anionic clay matrix; $\mathrm{Ag} / \mathrm{ZnLDH}$, nanosized silver/zinc-substituted anionic clay matrix ensemble; ZnLDH550, parent clay $(\mathrm{ZnLDH})$ calcined at $550^{\circ} \mathrm{C}$ for $20 \mathrm{~h}$; Ag/ZnLDH550, $\mathrm{Ag} / \mathrm{ZnLDH}$ calcined at $550^{\circ} \mathrm{C}$ for $20 \mathrm{~h}$.

Fig. 2. X-ray photoelectron spectroscopy (XPS) spectra of the nanosized silver/zincsubstituted anionic clay matrix ensemble $(\mathrm{Ag} / \mathrm{ZnLDH})$ with the close-up spectrum of Ag3d included.

Fig. 3. Peak fitting of the 01s spectrum for the as-synthesised, the thermal-treated and the re-constructed clay. ZnLDH, zinc-substituted anionic clay matrix; Ag/ZnLDH, nanosized silver/zinc-substituted anionic clay matrix ensemble; ZnLDH550, parent clay (ZnLDH) calcined at $550^{\circ} \mathrm{C}$ for $20 \mathrm{~h} ; \mathrm{Ag} / \mathrm{ZnLDH} 550, \mathrm{Ag} / \mathrm{ZnLDH}$ calcined at $550^{\circ} \mathrm{C}$ for $20 \mathrm{~h}$.

Fig. 4. Transmission electron microscopy image of the calcined clay (ZnLDH550) [the corresponding selected area electron diffraction (SAED) pattern is included].

Fig. 5. Transmission electron microscopy image of nanosized silver/calcined clay $(\mathrm{Ag} / \mathrm{ZnLDH})$ [the corresponding selected area electron diffraction (SAED) pattern is included]. 
Fig. 6. Fourier transform infrared (FTIR) spectra of the studied samples. ZnLDH, zincsubstituted anionic clay matrix; $\mathrm{Ag} / \mathrm{ZnLDH}$, nanosized silver/zinc-substituted anionic clay matrix ensemble; ZnLDH550, parent clay (ZnLDH) calcined at $550^{\circ} \mathrm{C}$ for $20 \mathrm{~h}$. 


\section{Table 1}

Chemical composition, surface and textural properties of the studied samples

\begin{tabular}{|c|c|c|c|c|c|c|c|c|c|}
\hline \multirow[t]{2}{*}{ Sample } & \multirow[t]{2}{*}{$\mathrm{Zn}: \mathrm{Al}$} & \multirow[t]{2}{*}{$\mathrm{Ag}$ (mass \%) } & \multirow[t]{2}{*}{$\mathrm{S}_{\mathrm{BET}}\left(\mathrm{m}^{2} / \mathrm{g}\right)$} & \multirow[t]{2}{*}{$d_{p}(n m)$} & \multicolumn{2}{|c|}{ O1s (\% peak area of the total area) } & \multicolumn{3}{|c|}{ Surface atomic ratio (\%) } \\
\hline & & & & & & $\mathrm{O}_{\|}$ & $\mathrm{O} / \mathrm{Zn}$ & $\mathrm{O} / \mathrm{Ag}$ & $\mathrm{O} / \mathrm{Al}$ \\
\hline $\mathrm{ZnLDH}$ & $2.0: 1.0$ & - & 79 & 38 & 32.9 & 67.0 & 4.76 & - & 7.52 \\
\hline ZnLDH550 & $2.1: 1.1$ & - & 134 & 29 & 42.8 & 57.1 & 3.34 & - & 4.79 \\
\hline $\mathrm{Ag} / \mathrm{ZnLDH}$ & $2.0: 1.0$ & 8.72 & 55 & 19 & 62.0 & 37.9 & 4.43 & 25.68 & 6.59 \\
\hline
\end{tabular}

$\mathrm{S}_{\mathrm{BET}}$, Brunauer-Emmett-Teller (BET) specific surface area; $d_{p}$, average pore diameter; ZnLDH, zinc-substituted anionic clay matrix; ZnLDH550, parent clay $(\mathrm{ZnLDH})$ calcined at $550^{\circ} \mathrm{C}$ for $20 \mathrm{~h} ; \mathrm{Ag} / \mathrm{ZnLDH}$, nanosized silver/zinc-substituted anionic clay matrix ensemble. 


\section{Table 2}

Zones of inhibition $(\mathrm{mm})$ against the tested bacteria of nanosized silver/zinc-substituted anionic clay matrix ensemble $(\mathrm{Ag} / \mathrm{ZnLDH})$ and unsupported silver nanoparticle $\left(\mathrm{Ag}_{\mathrm{N}}\right)$ samples as a function of $x$ (where $x$ is a controlled variable parameter that represents the length of time since the sample was synthesised)

\begin{tabular}{|c|c|c|c|c|c|c|}
\hline \multirow[t]{3}{*}{ Sample/bacteria } & \multicolumn{6}{|c|}{ Zone of inhibition (mm) } \\
\hline & $x=1$ & $x=1$ & $x=2$ & $x=1$ & $x=1.5$ & $x=3$ \\
\hline & day & week & weeks & month & months & months \\
\hline \multicolumn{7}{|l|}{$\mathrm{Ag} / \mathrm{ZnLDH} \mathrm{H}^{\mathrm{a}}$} \\
\hline Escherichia coli & 14.7 & 14.5 & 13.5 & 13.0 & 13.0 & 12.4 \\
\hline Staphylococcus & 11.9 & 12.7 & 11.0 & 10.5 & 10.0 & 7.0 \\
\hline \multicolumn{7}{|l|}{ aureus } \\
\hline \multicolumn{7}{|l|}{$\operatorname{Ag}_{N}{ }^{a}[14]$} \\
\hline E. coli & 12.4 & 11.5 & 7.5 & 5.0 & 5.0 & 3.0 \\
\hline S. aureus & 11 & 11.0 & 7.2 & 4.3 & 0 & 0 \\
\hline
\end{tabular}

${ }^{a}$ Concentration of silver $0.5 \mu \mathrm{g} / \mathrm{mL}$. 


\section{Table 3}

Minimal inhibitory concentrations (MICs) of the nanosized silver/zinc-substituted anionic clay matrix ensemble $(\mathrm{Ag} / \mathrm{ZnLDH})$ as a function of $x$ (where $x$ is a controlled variable parameter that represents the length of time since the sample was synthesised)

\begin{tabular}{lllllll}
\hline Sample & \multicolumn{7}{l}{ MIC values of $\mathrm{Ag} / \mathrm{ZnLDH}(\mu \mathrm{g} / \mathrm{mL})$} & \\
\cline { 2 - 7 } & $\begin{array}{l}x=1 \\
\text { day }\end{array}$ & $\begin{array}{l}x=1 \\
\text { week }\end{array}$ & $\begin{array}{l}x=2 \\
\text { weeks }\end{array}$ & $\begin{array}{l}x=1 \\
\text { month }\end{array}$ & $\begin{array}{l}x=1.5 \\
\text { months }\end{array}$ & $\begin{array}{l}x=2 \\
\text { months }\end{array}$ \\
\hline Ag/ZnLDH & & & & & & \\
Escherichia coli & 0.3 & 0.3 & 0.3 & 0.3 & 0.35 & 0.5 \\
Staphylococcus & 0.3 & 0.3 & 0.35 & 0.4 & N.D. & 0.7 \\
aureus & & & & & & \\
\hline
\end{tabular}

N.D., not determined. 


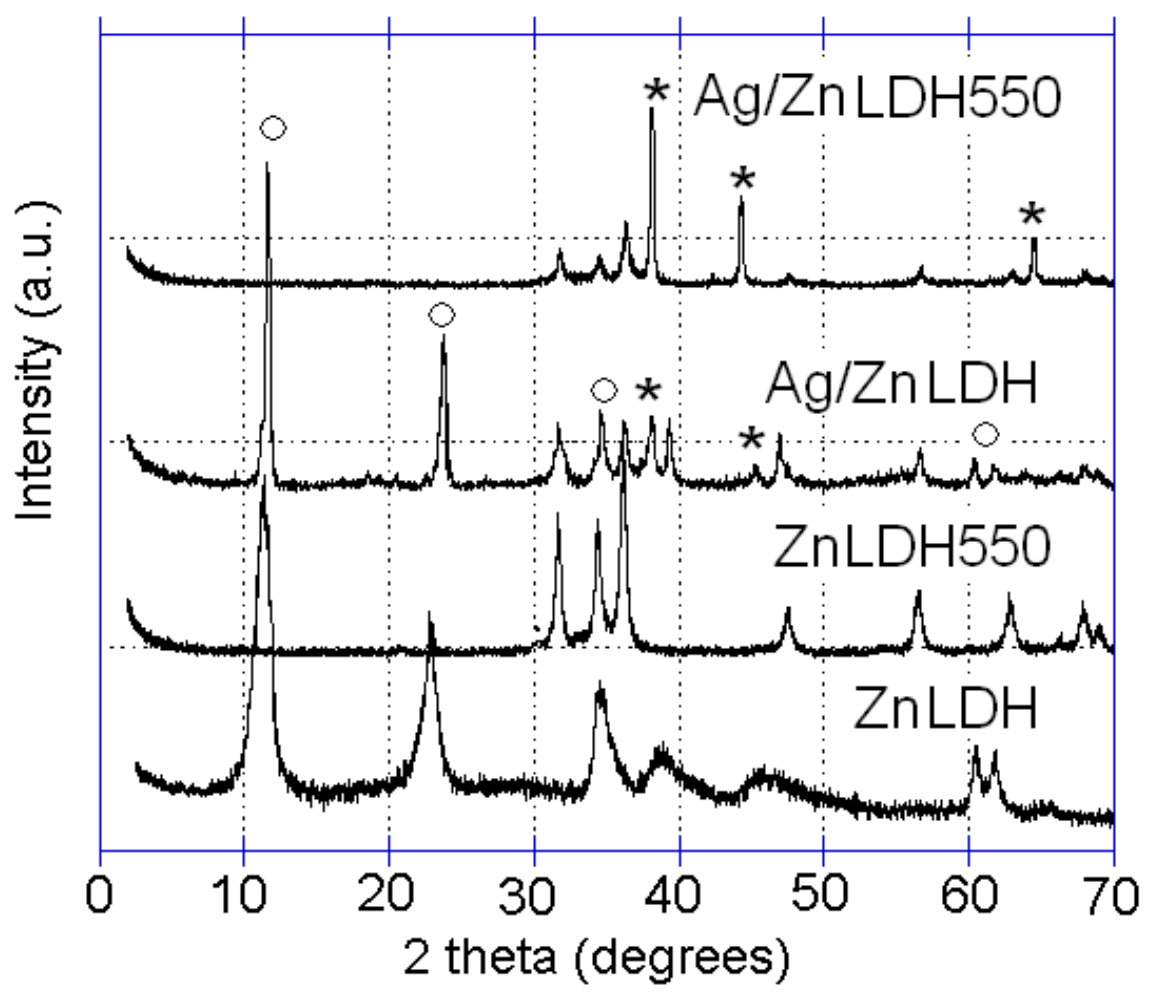




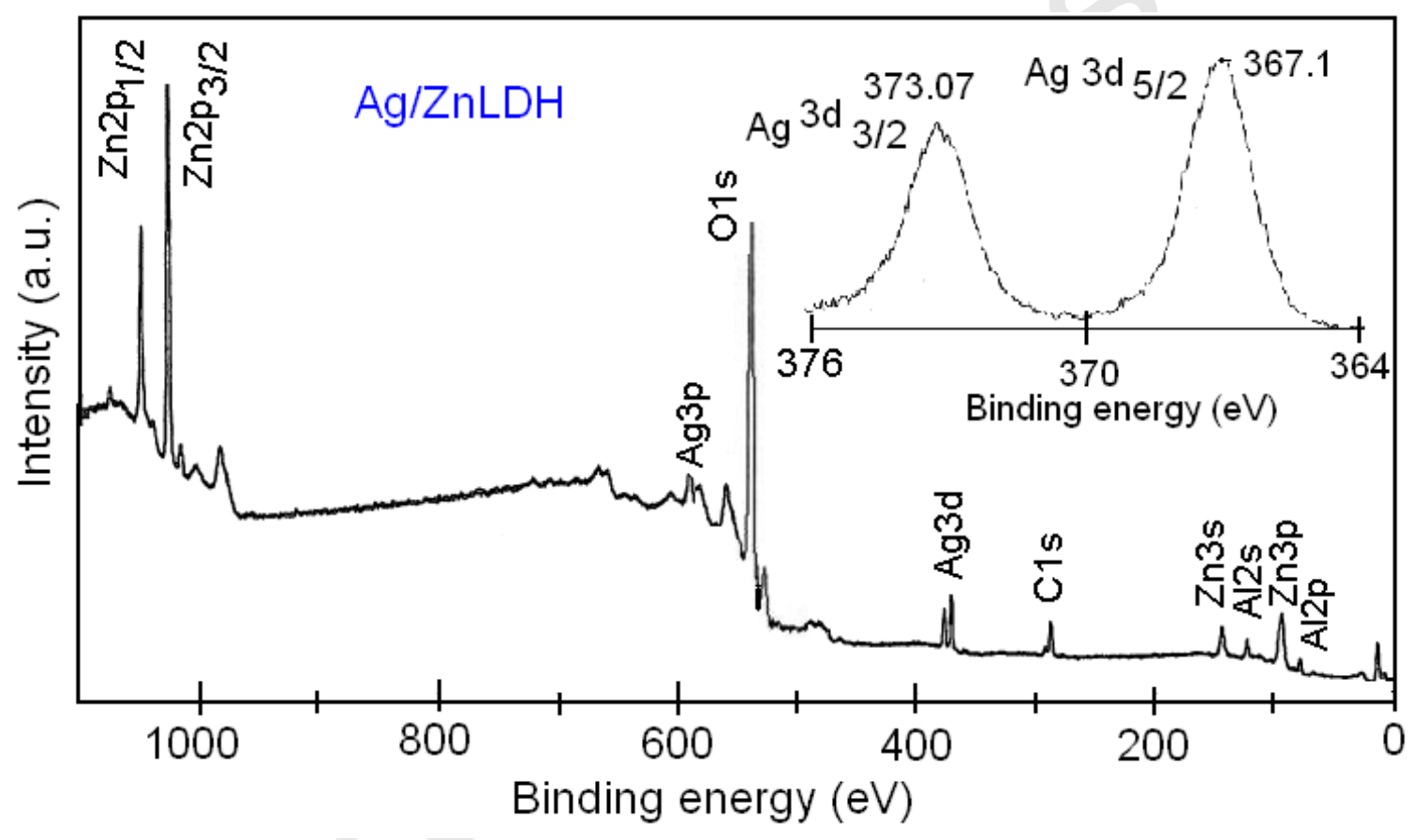




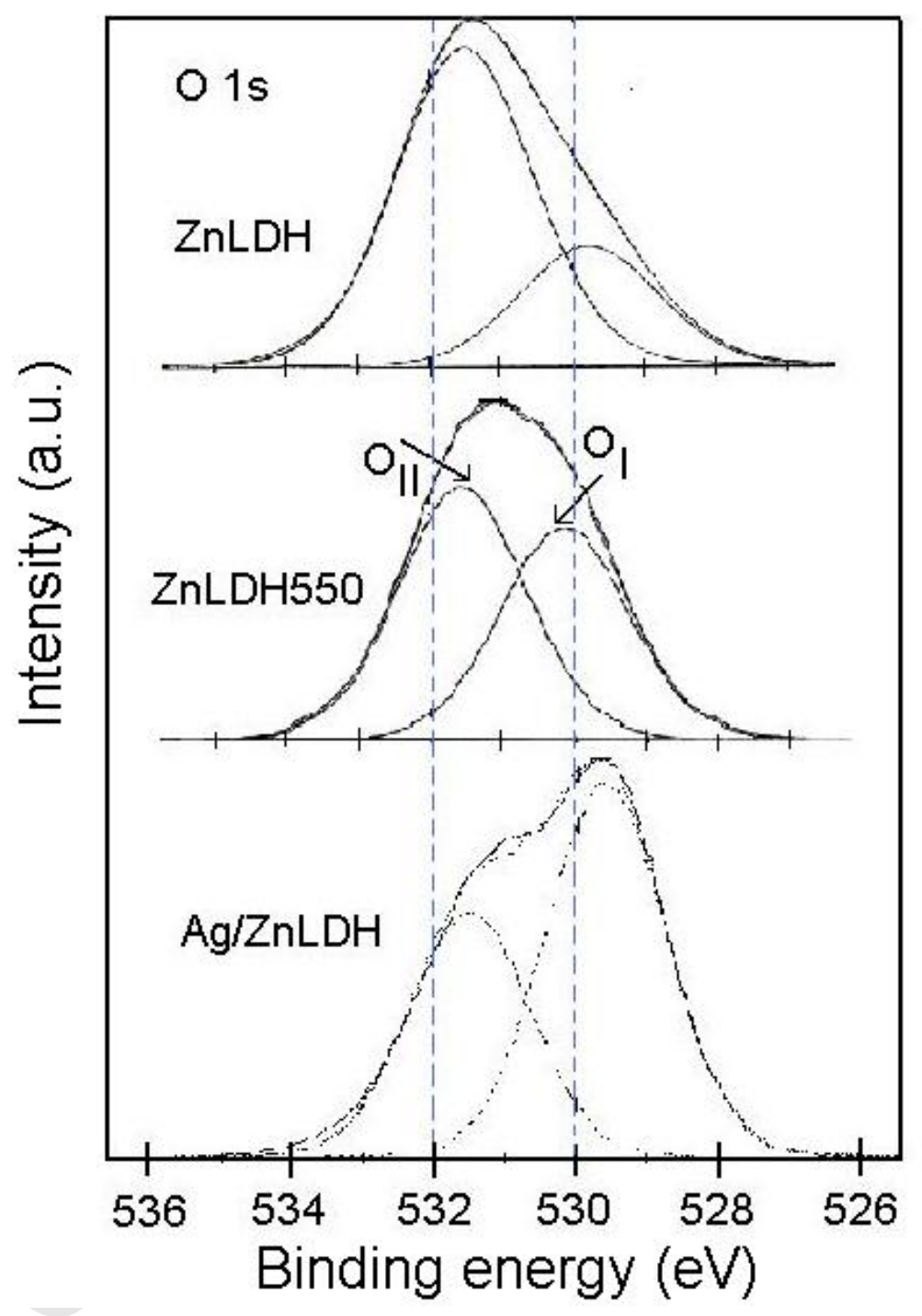




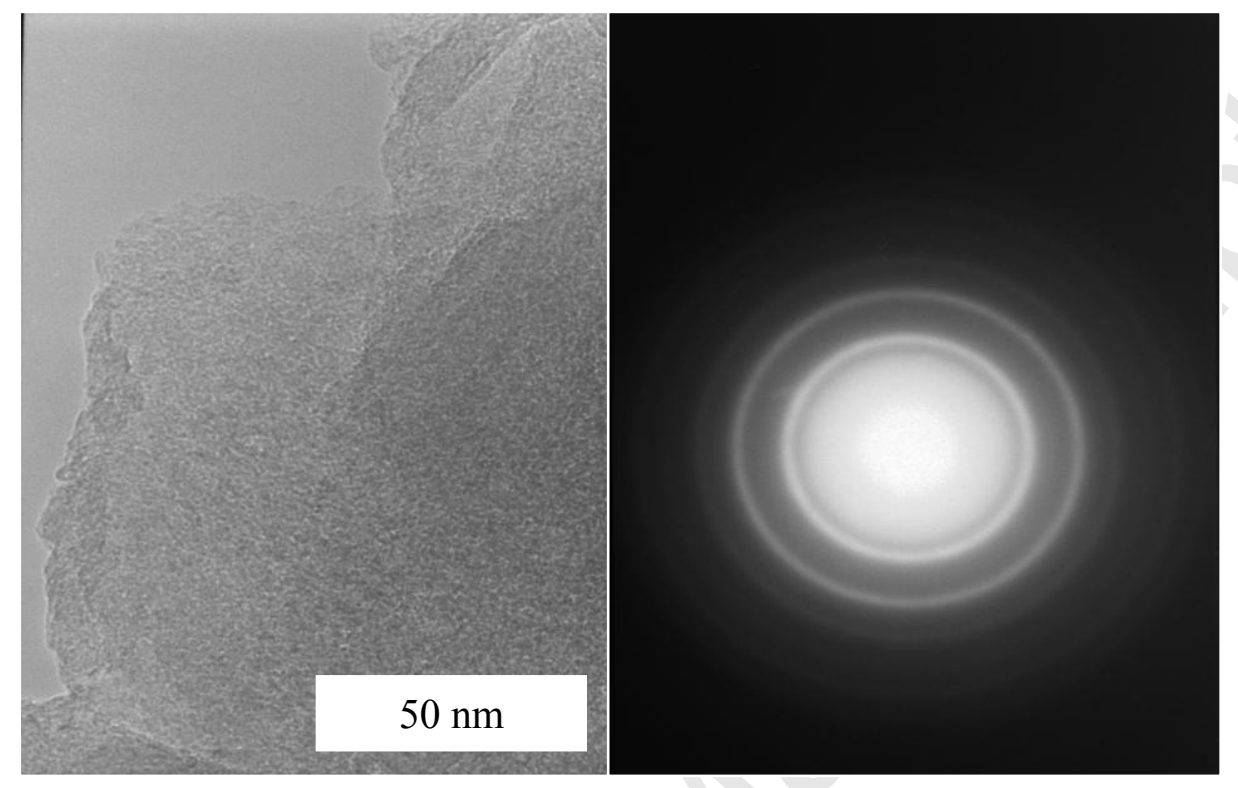

Page 27 of 29

Page 27 of 29




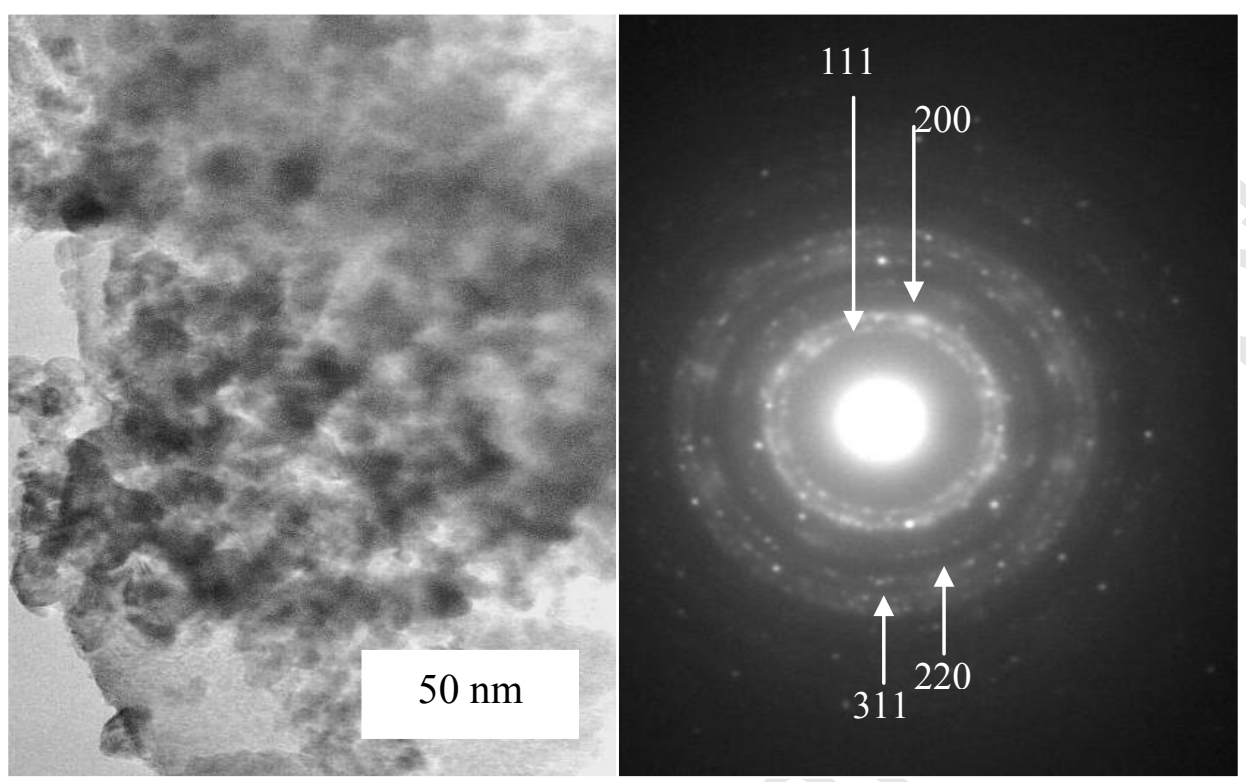

age 28 of 29

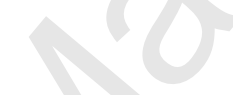

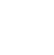

Page 28 of 29




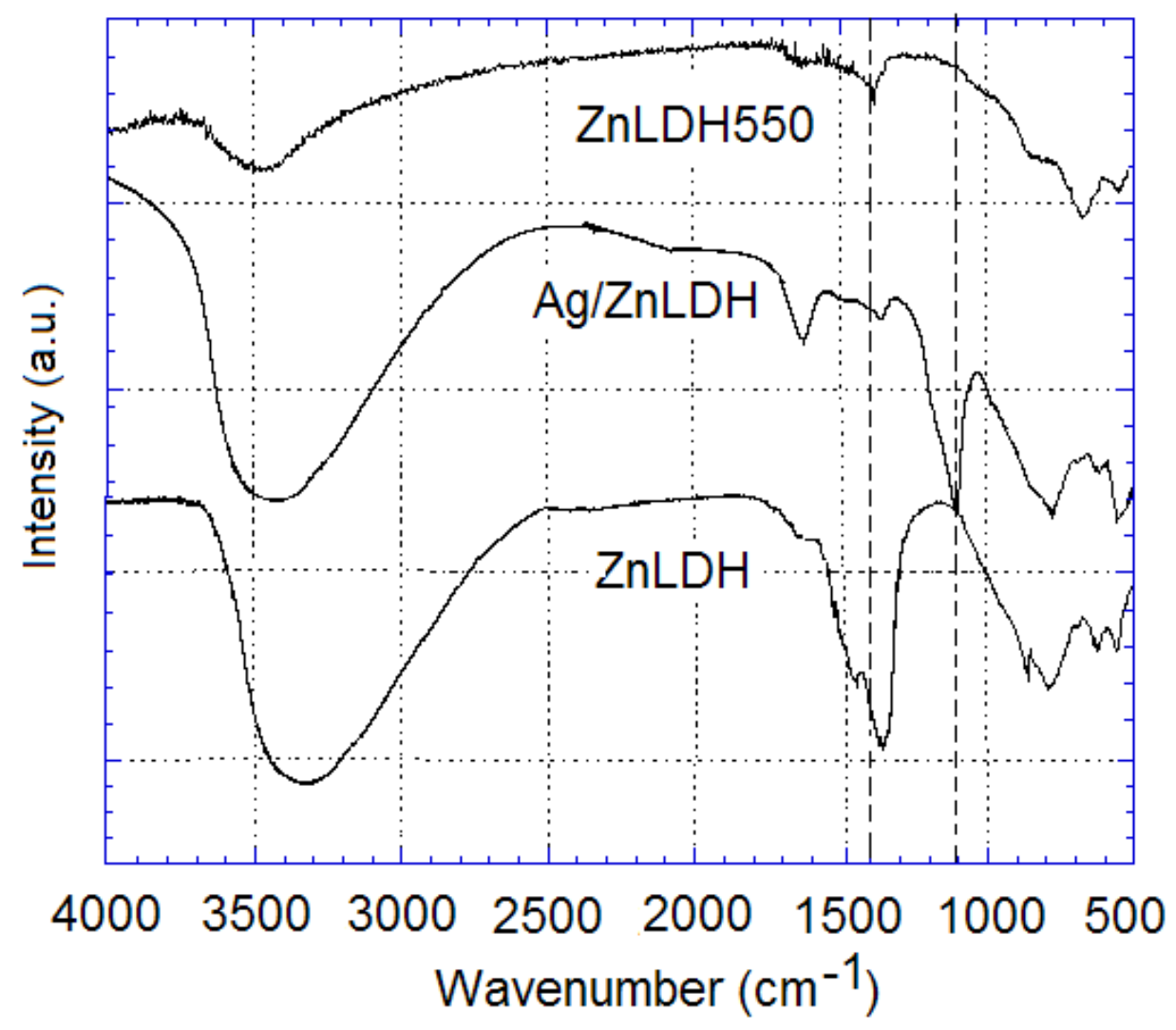

Figure 6. 